as in the case of Manouvriez, whero a hroncho-pneumonis appeared in the beginning, and was heralded two or three daya in advance hy convulsions.

Pleuro-pneumonin as a complication of varicella is illustrated hy an ohservation of Rille, who found it in an infant of nine months, and hy another of Ahercrombie, who at the autopsy upon a case of gangrenous varicella found a double pneumonia with a pleural exndate upon one side.

Finally, he reports an ohserration of Semtchenko relative to the autopsy upon a female infant of eleven months, who snccumbed to $n$ purulent pleurisy heginning threo daya after the complete disappearance of a varicellous eruption.

\title{
Forther Studieg on Indicandris.
}

To complete onr review of the literature bearing npon the value of the so. called Hochsinger's aign in tuherculosis of children (see AMER1CAN JornNAL OF THE MIEDIGAL ScIesces, Octoher, 1894, p. 492), reference must he made to two recent publications.

GEHLIG (Jahrbuch f. Kinderheilkunde, 1894, Ixxviii, p. 285) gives the following conclusions hased upon a considerahle number of ohservations upon children hoth aick and well:

1. Nurslings in good health or children fed upon sterilized milk, and not the suhjects of digestive troubles, sometimes present a trace of indican in the urine.

2. If digestive disturhances occur almost always some indican is found, its quantity rarying with the gravity of the affection. In chronic catarrh of the intestine, cholera, and ty phoid fever, it is particularly marked.

3. In older children without digestive trouhle the urine normally contains lndican. If the diet includes a high proportion of nitrogenous food (eggs, meat), indican hecomes more ahundant.

4. There exists no relation hetreen tuherculosis and a more or less marked indicanuria.

Ctus (Transactions Iniernational Congress of Rome, 1894) gives the results of examinations in sixty-eight cases. Most of these children were fed simply on hread nnd milk, aome on bouillon, regetahles, and eggs, and others on mother's or cow's milk.

1. Cases of clinically declared tuherculosis of ahdominal or thoracic organs-ten cases. Almost all had aome irregularity of digestion, and the atools were mostly liquid or semi-fnid. In ninety-nine analyses sixty-nine, or 69.69 per cent, gave positive reactions, while medium or very marked reactions were given in nearly half, or $\mathbf{4 5 . 5}$ per cent. In these same cases very marked resctions were ohtsined after aome days of feeding upon a diet richer in alhuminoids, or during constipation. On the other hand, the reaction was slight or feehle when the children were put upon milk or had liquid or semi-fiuid stools.

2. Cases suspected of tuhercnlosis, with adenopathy, chronic catarrh of intestines, or intermittent catarrh of hronchi-twenty-three cases. In seventy-three analyses, 75.34 per cent. positive reactiona, or 46.57 per cent. of medinm or marked reactions.

3. Cases of divers acute and chronic diseases-thirty-five cases. In eighty-eight examinations thirty-eight were without reaction, while 30 per 
cent. of medium or marked reaction were given for the most part hy children over two years of age nonrished on a mixed diet.

The conclusion from these results is that the indican reaction in the urine is more positively connected with anomalies of digestion, especially in mixed feeding, than with the principal malady. Consequently indican has no other diagnostic importance than that of indicating the degree of decomposition of nlbuminoid substances in tbe intestines.

\section{PATHOLOGY AND BACTERIOIOGY.}

UNDER THE CHABQE OF

JOHN SLADE ELY, M.D.,

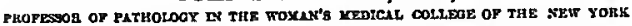

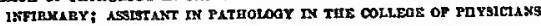

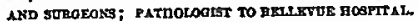

\section{IMMOATT: NATURAL AND ARTIFICIAL.}

ThE recent development of our ideas regarding immunity is traced in an interesting paper by BochNer, read before tbe Eigbtb Internntional Congress of Hygiene and Demograpby at Buda-Pesth (Afünch, med. Woeh., 1894, Nos. 37 and 38 ), in wbicb tbe essential differences between tbe nntural immunity of certain animals to bacterial infuences nnd tbe immunity nrtificially conferred by experiment are empbasized. The elaborate nrgument embodying the results of the investigations of tbe past tbree years is summed up in the following conclusions:

1. The nntural potver of resisting in fection, the so-called natural immunity, depends upon distinctly different conditions and causes from tbe nrtificially induced immnnity. Tbey are, tberefnre, essentially diferent conditions, wbicb, from the scientific stand point, shnnld be kept quite distinct from one another, and investigated ench for itself, althongb practically tbey may be coexistent in the same individual.

2. Natural immunity depends, on the one hnnd, nn the bectericidal action of certain substances in solution in the nrganism, the so-called alerines, or. on the other hand, on an inherited insusceptibility of the tissues and cells of the body to the several bacterial poisons. This natural immunity cannot, as a rule, he transmitted to the hody of annther animnl by means of the hlood.

3. Tbe leucocytes play an important rôle in tbe protection of the body hy natural immunity, not as phagocytes, bnt through the action of soluhle suhstrnces secreted by them. Phagocytosis is nnly a secondnry function.

4. Artificial or acquired immunity depends nn the presence of modified specific bacterial products, the so-called antitoxines, either in the hlood, in the tissues, or in hoth. By transfer of the hlood these specific antitoxines can he transmitted to another organism, therehy conferring upon it artificial immnnity.

5. The nction of the antitoxines dnes nnt depend upon destruction of the specific hacterial poisons by contact with them, bnt occurs only in the animal 